\title{
近接地域との比較に基づく現存北海道産哺乳類について
}

閒崎 允 昭 ${ }^{1}$

\section{Present Status of Mammals of Hokkaido as Considered from That of Adjacent Territories}

\author{
Masaaki $\mathrm{K}_{\mathrm{ADOSAKI}}{ }^{1)}$
}

\begin{abstract}
From the study of fossils the present status of mammals in Japan is considered to have appeared since the Diluvian epoch of Quaternary. Most of the present mammals in Japan show close relation to those of the Asiatic Continent and the distribution pattern shows that there occurred animal interchange between the both areas in ancient times. Prototype of mammalian fauna of Hokkaido seems to have been constructed up to Post-glacier period after the isolation of Hokkaido from the neighbouring areas. At present, mammalian fauna of Hokkaido includes $19 \mathrm{sp}$. and 34 subsp. belonging to 34 genera, 14 families, 6 orders (see Table 1). The characteristic of mammalian fauna of Hokkaido is consisted in a mixed existence both of northern cold zone species and of southern temperate zone species including some great sphere ones. There are many marine animals which are rare in the Main Island. The existence of many northern cold species in Hokkaido and South-Kuriles shows close faunal relation to Sakhalin and Primorskii. Three genera of the vole, namely Clethrionomys, Aschizomys and Eothenomys; two species of the shrew, namely Sorex minutissimus and Sorex hosonoi; two species of the squirrel, namely Sciurus vulgaris and Sciurus lis; and two species of the hare, namely Lepus Brachyurus and Lepus timidus are very similar respectively in all aspects. However, no phylogenetic study of the animal has been made, though the matter is very interesting. The occurrence of Crocidura dsinezumi, Sorex minutissimus and Ochotona hyperborea in Hokkaido is particular. Their ecological and zoogeographical studies are necessary. More species of mammals in Kuriles may be added in future.
\end{abstract}

\section{I 緒言}

北海道は日本列島最北の島で北方大陸に接近し，その 地理的環境から動物地理学上非常に興味ある地域となっ ている. 北海道の動物相について初めて考察を試みたの は BLAKISTON \& PRYER (1880) • BLAKISTON (1883) であった．彼らは主として鳥相および哺乳相の上から， 北海道をサハリン・沿海州と同様の動物相区とした.こ れに対し，HATTA(1913)は主として爬虫・両生相の上か ら, 北海道をサハリン・沿海州区域から除外し, 本州以 南地域と同様の動物相区とした. 以来多くの研究者によ り各動物群・各個体群についてこの問題は論じられ今日 に至っている.
筆者はここに北海道産哺乳類について, 主として極東 地域に産する共通種との比較を基に, 分布および分類記 載上の実態を述へ, 北海道産哺乳類の由来, 哺乳相の特 徴と動物区, 分類学および分布上の問題点などについて 考察を試みることにする.なお，本稿を記すに当たり犬 飼哲夫博士にご教示いただいたことをここに記し, 感謝 の意を表したい.

\section{II 北海道産哺乳類の実態}

北海道産哺乳類は, 近年絶滅したものも含めて, 6 目 14 科 34 属 19 種・ 34 亜種の 53 種類が記載されている(表 1 ). 次に各種類について，その実態を述べる.

食虫目は次の 1 科 2 属 3 種 2 亜種を産する.

1）北海道開拓記念館(Historical Museum of Hokkaido) 
トウキョウトガリネズミ Sorex minutissimus hawkeri ; S. minutissimus は東シベリアからサハリン・ 北海道にか外分布する。 日本産は HAwKER が Yedo, Inukawa; Hondo で採集した 1 頭を基に THOMAS (19 07）が S. hawkeri と記載したが，その後本種はСтрогAHOB (1957)により S.minutissimus の亜種として記載さ れた. HAWKER 以後, 本州からの採取例がなく，江戸 には犬川の地名も無い事から, Yezo, Mukawa (北海道) の誤記との見解がある（阿部，1961）。北海道では1957 年以来，東部と北部のいづれも平地で採集され，阿部 （1961）はこれを S. m. hawkeri と同定した. 近縁種と して沿海州・サハリンには S. m. hawkeriよりやや小形 の $S . m$. tscherskii OGNEV 在産する. 北海道の属島打 よび千島からの採集例はない. カラフトヒメトガリネズ ミSorex gracillimus; 本種は東シベリアから中国北 東部・朝鮮北部・サハリン・北海道にか汁分布する. 従 来, 本種はS. minutus gracillimus THOMAs と記載されて
いたが， Юдин（1965）により，主として頭骨と陰茎の 形態から独立種とされた．北海道では利尻・礼文を含む 各地に分布し, 南部では特に山岳地に多く, 北部では平地 にも多い、干島からの採集例はない.エゾトガリネズミ Sorex caecutiens saevus : S. caecutiens はューラシア 大陸とその属島の主として冷温蒂以北に分布する.北海 道・サハリン・国後島にはS. caecutiens saevus が分布す る. 岸田 (1923), KurodA (1928), 今泉 (1960) らは 本種を S. shinto saevus THOMAs と記載した. その後黑 田（1953）は本種をS. caecutiens の地方型とし, S. caecutiens Kuroda とした. ABE (1967) は EllERMAN \& MORRISON-SCOTT (1951) の記載を採用し, 北海道産 をS. caecutiens saevus とした. 北海道では平地から山岳 地带にかけ各地の灌木林・森林地带に広く分布する。本 州では中部以北の山岳地带に別亜種 S. c. shinto THOMAS が，四国の山岳地带には S. c. shikokensis. n. subsp. が 分布する. THOMAS (1907) は北海道産が本州産に比べ, 表 1

\begin{tabular}{|c|c|c|c|c|c|c|c|c|c|c|c|c|c|c|c|c|c|c|c|}
\hline & Species & 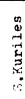 & 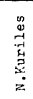 & 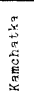 & 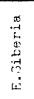 & 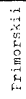 & 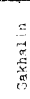 & $\begin{array}{l}8 \\
0 \\
0 \\
0 \\
0 \\
0\end{array}$ & $\begin{array}{l}0 \\
0 \\
0 \\
0 \\
0\end{array}$ & 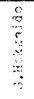 & 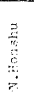 & 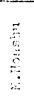 & $\begin{array}{l}3 \\
\therefore \\
:\end{array}$ & 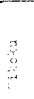 & $\begin{array}{l}3 \\
\frac{3}{3} \\
z\end{array}$ & 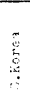 & 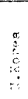 & & \\
\hline \multicolumn{20}{|l|}{ INSECTIVOKA } \\
\hline \multirow[t]{5}{*}{ SORICIDAE } & 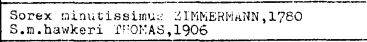 & & & & & & & $\cdots$ & $\ldots$ & & & & & & & & & & \\
\hline & Sorex gracillimus THOMAS, 1907 & & & & & & & - & & - & & & & & & & & & \\
\hline & $\begin{array}{l}\text { Sorex cuecutiens LAXNANi, } 1788 \\
\text { S.c.spevas THOMAS, } 1907\end{array}$ & F & & & & & 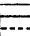 & $\ldots$ & $\ldots$ & $\ldots+$ & & & & & & & 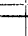 & & \\
\hline & Jorex unguiculatus DoBSON, 1890 & & & & & & & & & - & & & & & & & & & \\
\hline & Crocidura ds inezumi (TiblikirCh, 1844) & & & & & & & & 7 & - & & & & & - & & & & \\
\hline \multirow{3}{*}{$\begin{array}{l}\text { CHIFOPTERA } \\
\text { HHINOLOPHIDAE }\end{array}$} & & & & & & & & & & 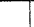 & & & & & & & & & \\
\hline & 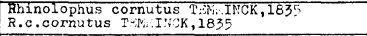 & & & & & & & & & $\cdots$ & & & & $\cdots$ & $\cdots$ & & & & \\
\hline & $\begin{array}{l}\text { Rhinolophus ferrumequinum(SCHREBER, 1774) } \\
\text { R.f.nippon TEMM INCK,1835 }\end{array}$ & & & & & & & & & 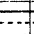 & & & 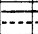 & -. & $\cdots$ & $\cdots$ & $\cdots$ & & \\
\hline \multicolumn{2}{|c|}{ VESPERTILIONIDAEMyotis macrodact.Jlus(TEMMINCK, 1840) } & F & & & & & & & & & & & & - & & & & & \\
\hline & $\begin{array}{l}\text { Myotis daubentonii(KUHL, 1819) } \\
\text { M.d.ussuriensis OGNEV, 1927 }\end{array}$ & $=$ & & & & & $\ldots$ & & 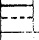 & & & & & & & $\cdots$ & $\cdots$ & & \\
\hline & Myotis hosonot IMAIZUMI, 1954 & & & & & & & & & - & & & & & & & & & \\
\hline & $\begin{array}{l}\text { Myotis frater G.M.ALIERN, } 19.23 \\
\text { M.f.kaguyae IMAIZUMI, } 1956\end{array}$ & & & & & 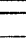 & & & $-\cdots$ & 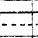 & & $\cdots$ & & & & & & & \\
\hline & Myotis ikonnikovi OGNEv, 1912 & & & & & & & 7 & $t$ & & & & & & & & 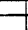 & - & \\
\hline & $\begin{array}{l}\text { Myotis nattereri (KUHL, 1818) } \\
\text { M.n.ssp. }\end{array}$ & & & & & 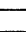 & & & $\cdots$ & & & & & & & & & & \\
\hline & Vespertilio superans THOMAS, 1899 & & & & & & & - & - & - & & - & & - & & - & - & & \\
\hline & Nyctalus lasiopterus (SCHRERER, 1870) & & & & & & & & & - & - & - & & & & & & & \\
\hline & N.1.aviator THBOMAS, 1911 & & & & & & & & & $\cdots$ & $\cdots$ & $\ldots$ & $\cdots$ & $\cdots$ & ... & & & & \\
\hline & $\begin{array}{l}\text { Fipistrellus savii (BOHAPARTE, 1837) } \\
\text { P.s.velox(OGNEV,1927) }\end{array}$ & & & & & $\cdots$ & & & & $\cdots$ & & & & & & & & & \\
\hline & $\begin{array}{l}\text { Plecotus auritus (I.INMAEUS, 1758) } \\
\text { P.Q.sacrimontis G.M.ALLEN, } 1908\end{array}$ & F & & & & & $\ldots$ & $\cdots$ & $\cdots$ & $\cdots$ & $\cdots$ & 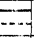 & & 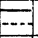 & & - & & & \\
\hline & $\begin{array}{l}\text { Murina aurata MILNE-EDWARDS, } 1872 \\
\text { M.Q.ussuriensis OGNEV, } 1913\end{array}$ & & & & & $\cdots$ & & $\cdots$ & - & $\ldots$ & $\cdots$ & $\ldots$ & $\cdots$ & $\cdots$ & & & $\cdots$ & & \\
\hline & $\begin{array}{l}\text { Barbastella leucomelas (CRETZCHMAR, 1826) } \\
\text { B.1.derjelingensis (HODGSON) 1855) }\end{array}$ & & & & & & & & $\ldots$ & $\ldots$ & & $\ldots$ & & $\cdots$ & & & & & \\
\hline MOLOSSIDAE & Tadarida Insignis(BLYTH, 1861) & & & & & 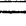 & & - & & & & & & & & & & & \\
\hline \multicolumn{20}{|l|}{ LAGOMORPHA } \\
\hline OCHOTONIDAE & $\begin{array}{l}\text { Ochotona hyperbores(PALLAS, 1831) } \\
\text { 0.h.yesoengis KISHIDA, } 1930\end{array}$ & & & & & & & $\cdots$ & & $\cdots$ & & & & & & & & & \\
\hline LEPORIDAE & 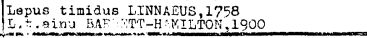 & & & & & & & 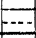 & - & $\cdots$ & & & & & & & & - & \\
\hline \multicolumn{20}{|l|}{ FODENIIA } \\
\hline \multirow[t]{3}{*}{ SCIURIDAE } & $\begin{array}{l}\text { Sciurus vilearia LINUSAUS, } 1758 \\
\text { S.v.orientis THOMAS, } 1906\end{array}$ & & & & & & & $\cdots$ & $\cdots$ & $\ldots$ & & & & & & & & & \\
\hline & 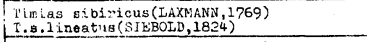 & & & - & & - & $\ldots$ & $\cdots$ & $\cdots$ & $\cdots$ & & & & & & & & & \\
\hline & 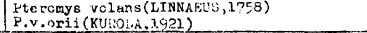 & & & & & & & & & $\cdots$ & & & & & & & & & \\
\hline
\end{tabular}




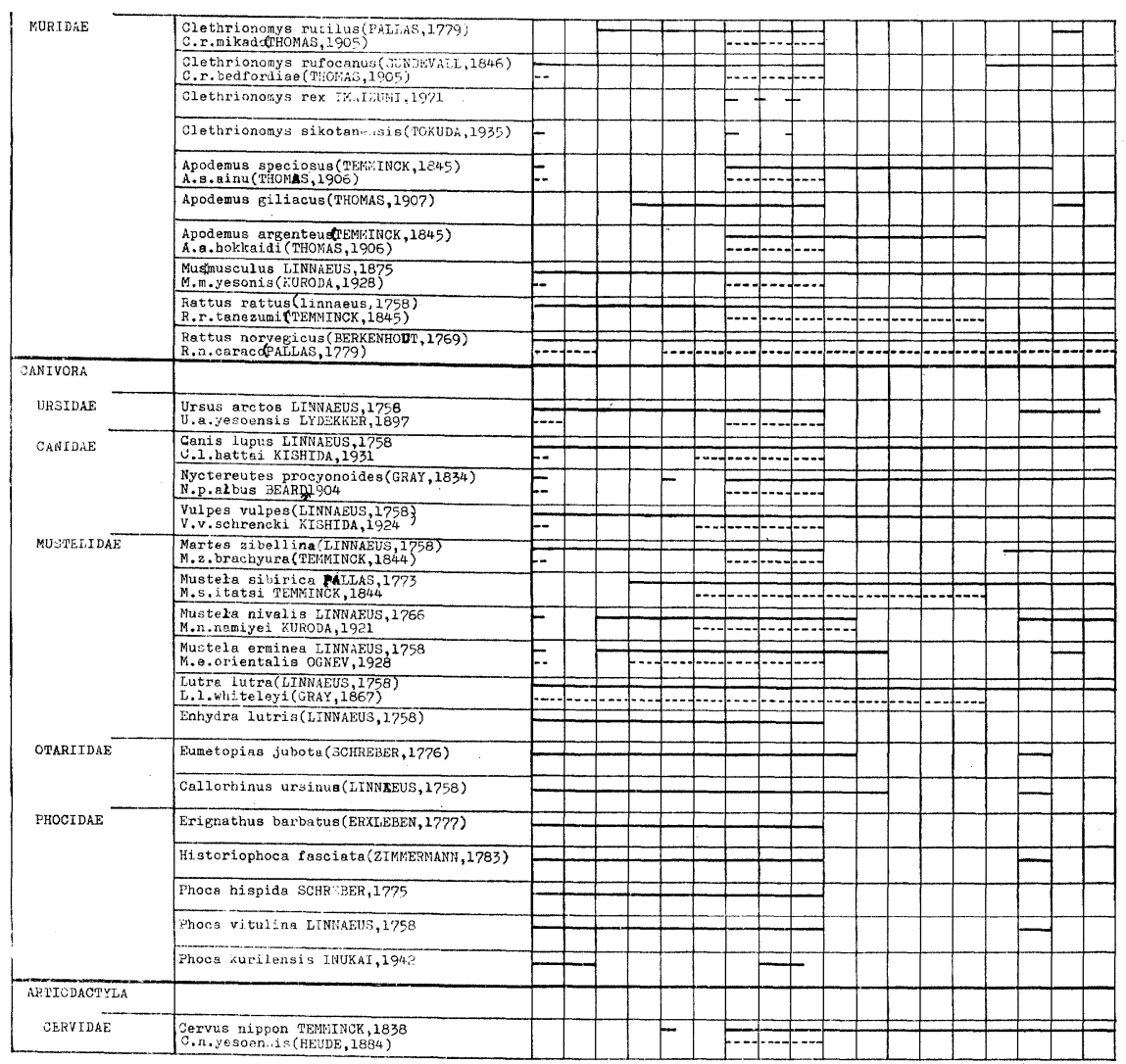

体長・頭骨の大きさが僅少差大きいことを理由に各々を 西種とした.オオアシトガリネズミSorex unguiculatus : 本種は東シベリアから中国北東部・サハリン・千 島・北海道とその属島にかけ分布する. 北海道では草地 や灌木林に特に多い. ELLERMAN \& MORRISON-SCOTT (1951) は本種を S. araneus fretalis MILLER と同定した が， ABE (1967） は前肢と歯の形態から北海道産を $S$. unguiculatus とした. 岸田（1924）は本種の他に北海道 には,シベリア・サハリンに産する別種 S. daphaenodon THOMASが産するとし, 根室産にS. daphaenodon yesoensis KISHIDA と記載した。これに対し，今泉 (1960) はサ ハリン産の $S . d$.daphaenodon と比較し，岸田の記載種を S. unguiculatus の幼獣との見解をとり，ABE (1967) は $S$. unguiculatus の個体変異との見解をとっている. ジネズ ミCrocidura dsinezumi : 本種は日本固有種で, 北 海道から九州・薩南諸島にかけ分布する.北海道では札 幌（藻岩）と芦別から採集されている. 北海道の属島と 千島加の採集例はない，今泉(1960)は本種を便宜的に C.d.dsinezumi, (Temminck), C.d.chisai Thomas, $C$. d. okinoshimae KurodA, $C$. $d$. intermedia Kuroda, $C . d$. umbrina (TEMMINCK), C.d. orii KURODA の6 亜種に細 分した.これに対し ABE (1967) は前 4 亜種はいづれも 体長・体色とも連続的地理変異を示すとの理由により亜 種に分けることに異論を示している.

翼手目は次の 3 科 9 属 5 種・10互種を産する. ニホン コキクガシラコウモリ Rhinolophus cornutus cornutus : R. cornutus は中国南部と日本に分布する．日 本産は 5 亜種からなる. 北海道から九州にかけては, や や大形の R. c. cornutus を産し, 南西諸島には前腕長 $37 \mathrm{~mm}$ 以下のやや小形の 3 亜種 R.c.orii KURODA, R.c.pumilus ANDERSEN, R. c. miyakonis KURODA と, やや大形のR. c. perditus ANDERSEN を産する. 北海道では南部でのみ 採集されている. ニホンキクガシラコウモリ Rhinolophus ferrum-equinum : 本種は旧世界の温・熱帯地 方に広く分布する. 日本産は $R . f$. nippon TEMMINCK と R.f. mikadoi OGNEv の 2 亚種からなる. R. f. mikadoi は OGNEV (1927)が横浜産に対し, 前腕長と頭骨全長が R.f.nippon より大きいことと,体色に赤味がないことを 
理由に別亜種としたものである.しかし，黒田（1940） はR.f. mikadoi を検し，R. f.nippon と区別しえないと 報告している. 今泉(1960)は北海道産は $R . f$. mikadoiで あろうと推定していたが，服部(1971)は北海道産を検し， 前腕長と頭骨全長が前記両亜種の中間值を示し，画然と 区別しえなかったことを報告し，黒田の見解を支持して いる.なお，黑田（1940）はR.f.nippon の中に加令的 体色変異を認めている. 北海道では東部と北部で採集さ れている．野沢（1894）は南千島にも本種が産すること を報告しているが，詳細は不明である，モモジロコウモ リMyotis macrodactylus : 本種は日本特産で北海道 加九州にかけ分布する．黒田（1940）は国後島にも産 すること報告している，北海道では南部と東部で採集 されている. 今泉 (1963) は本州産を検し, 後足につく 飛膜の位置に個体変異の存在を報告しているが，服部 （1971）は北海道産にはそのような変異が認められない と述べている．ウスリドーベントンコウモリ Myotis daubentonii ussuriensis : $M$. daubentonii は旧北区に 広く分布し，3亜種が知られている。アジア東部には OGNEV (1927) が記載した M.d. ussuriensis だけが分布 し，日本では北海道の宋部だけで採集されている（服部， 1971). 本種は他の 2 严種より小形である. シナノホオ ヒゲコウモリ Myotis hosonoi : 本種は IMAIZUMI (19 54）が初記載した種で，日本特産で，しかも本州中部以 北の山岳地と北海道の札幌市内で採集されたに過ぎない. カグヤコウモリ Myotis frater kaguyae : M. frater は中国・沿海州南部・朝鮮・日本に分布し，4亜種が知 られている. 日本産は M.f. kaguyae で，本州中部以北 と北海道の東部と南部で採集されている.今泉 (1960) は本種が, 耳珠の形態・尾が短小な点, 踵骨の後葉が痕 跡的である点老指摘し, 中国産 $M . f$. frater G. AlLEN や沿海州産 $M . f$. longicaudatus OGNEV より，一層原始 的な亜種であろうと推論している.ヒメホオヒゲコウモ リMyotis ikonnikovi：本種はモンゴル・中国北東部 ・朝鮮・沿海州・サハリン・日本に分布する、日本では 北海道の中央部でのみ採集されている（今泉，1960）. 本種が北海道に産することは，既に岸田・森 (1931) が 報告していたが，確実な採集記録がないことから疑問視 されていた（今泉，1949）. ノレンコウモリ Myotis nattereri : 本種は旧北区に広く分布する. 本州と九州 には M. n. bombinus THOMAS を産する。服部 (1971) は北海道産 1 頭を㭘し, $M$. nattereri の諸形質を具備し ているが，今泉 (1954) が記載した本州産と比べ，前腕 長・耳介の形態・上顎前臼歯の横断面に差異が見られる
とし $M$. nattereri ssp. と同定した。 ヒナコウモリVes pertilio superans: 本種は中国・朝鮮・東シベリア・ サハリン・日本に分布する。日本では北海道・本州中部 以北・四国・九州の大机島に産し，北海道には多い，服 部 $(1966,1971)$ は北海道産を㭘し, 加令的体色变異が 大きいことを報告している.ニホンャマコウモリ $N y c$ talus lasiopterus aviator : N. lasiopterus はヨーロッ パ・中国・朝鮮・日本に分布する. 日本産は基垔種より 小形の N.l. aviator で，全土に分布するが北海道には 少なく，道南だけで採集されている．クロオオアブラコ ウモリ Pipistrellus savii velox : p. savii はユーラシ ア大陸に広く分布する。しかし日本ては極めて稀で，対 島と札幌で採集されているにすぎない(IMAIZUMI, 1955, 今泉, 1970 ; 服部, 1966). 日本産は沿海州と共通の P.s. velox OGNEv である. ニホンウサギコウモリPlecotus auritus sacrimontis : P. auritus はューラシア大陸・ サハリン・日本・南下島に分布する。極東地域には $P$. a. sacrimontis G. M. AlLEN と P. a. ognevi KISHIDA の 2 更種在産する（岸田, 1924 ; 黒田, 1940). 黒田(19 40)はこれら 2 亚種の差異について P. a. ogneii は幾分 小形で，体色が黒味を带びているので区別可能であると した、今泉 (1949) は体色により2覀種の区別を武みた が，その後 (1960） 2 亜種に細分することの不合理を指 摘し, P. a. ognevi をP. a. sacrimontis のシノニムとし た. 服部 (1971) も今泉の見解に同意し, 北海道産を P. a. sacrimontis と同定した. ニホンコテングコウモリ Murina aurata ussuriensis : M. aurata は中国・ 朝鮮・沿海州・サハリン・日本に分布する.日本産は中 国北東部加ら朝鮮・沿海州・サハリンにかけて広く分布 する M.a.ussuriensis である. チチブコウモリ Barbastella leucomelas darjelingensis : B. leucomelas 中央アジアから中国・インドシナ・日本に分布する．日 本産はコーカサスから中国にかけて分布する B.l. darjelingensis である. 本州では稀な種とされているが，北海 道では近年続けて採集されている。オヒキコウモリ

Tadarida insignis : 本種は中国・朝鮮・沿海州・日本 に分布する. 日本では福島県沖の島(阿部余四男，1944） - 焼尻島 (阿部, 1961) ・熊本市内 (今泉・吉行, 1965) から各 1 頭採集されているにすぎない，今泉（1960）は 日本産を Tadarida teniotis RAFINESQUE の亜種 $T$. $t$. insignis としたが，再検討の結果 $T$. insignis と訂正した (今泉・吉行, 1965).

兔目は次の 2 科 2 属 2 亜種を産する.エゾナキウサギ Ochotona hyperborea yesoensis : O. hyperboreaはつ 
ジア大陸に広く分布し, 西はウラル山脈から東はカムチ ヤッカまで, 南はモンゴル・中国北東部まで, その他, 朝 鮮北部・サハリン・北海道に分布する. 北海道産は $O . h$. yesoensis で, 主として山岳地带に広く分布しているが, 稀 に比較的低地带にも産する. KISHIDA(1930) は本種を含 めて北海道産老O. kobayashii, O. ornata, O.sadakei, O.rufa, O. inukaii, O. convexa, O. kinuta の8 種に細分したが, その根披は明確でない（黒田, 1938 ; 今泉, 1949, 1970). サハリンには別亜種 O. h. yoshikurai KISHIDA を産する が O. h. yesoensis との差異は不明である. 知床・千島か らの採集栵はない.

エゾノウサギ Lepus timidus ainu : L. timidus は シベリアから中国北東部・サハリン・北海道とその属島 - 南千島に広く分布する. 本州から九州にかけては別種 Lepus brachyurus TEMMINCK が，中国北東部・朝鮮・沿 海州には別種 Lepus mandshuricus RADDE が分布するが (ElleRMAN \& MORRISON-ScotT 1938), これら 3 種を各々独立種とすることについては，更に検討が必要 である，日本とその近接地域のノウサギを記載するに当 たり，黒田（1938）は本州北部産支L. brachyurus angusiidens HOILLISTER, 本州中部以南・四国・九州産を L. b. brachyurus TEMmINCK \& SCHLAGEL, 北海道産を $L$. timidus ainu, サハリソ産をL. $t$. orii KURODA，エトロ フ産を L. $t$. abei KURODA などとした. 令泉 (1949) は日本産ノウサギを総て L. timidus とし, 地理的変異の 亜種を認めていたが，その後(1960)北海道産と本州以南 産は，尾長と鼻骨の発達差などから別種であるとし, 北 海道産を L. $t$. ainu, 本州以南産を L. brachyurus とした. 更に L. brachyurus については，体の大きさ，特に足長 の差異から, 一応地理的変異の亜種を認めつつも, それ が不連続的変異であるか否かについては疑念を示してい る.

㙞歯目は次の 2 科 7 属 3 種・10亜種を産する.

エソリス Sciurus vulgaris orientis : S. vulgaris はユーラシア大陸の冷温带以北とサハリン・北海道に分 布する. 北海道産は S. v. orientis で，森林地带に広く 分布している. 岸田 (1924) ·黒田（1938）らは日本産 リスを記載するに当たり, 北海道産を S. v. orientis, 本 州・四国 -九州産を S. lis TEMMINCK \& SCHLEGEL と 別種にした. 一方, 今泉 (1949) は日本産を総て S. vul galis とし, 北海道産を S. v. orientis, 本州以南産を $S$. v. lis としたが, その後, 岸田・黒田の記載法を採用し た今泉 (1960) は， S. vulgaris とS. lisの差異とし て, 頭骨の大きさと尾端の毛色を指摘している. なお,
S. vulgaris の地方型として，サハリンにはS. v. rupestris THOMAs を, 朝鮮には $S . v$. coreae SowARBY を産す る. 岸田 (1924) はS.v. rupestris がS.v. orientis より 小さいこと, S. v. orientis と S. v. coreae が酷似してい ることを報告している.千島からの採集例はない。エソ シマリス Tamias sibiricus lineatus ; T. sibiricus は中国北東部・朝鮮から東シベリア・サハリン・北海道 ・南千島に分布する．本州以南には産しない. 北海道・ サハリン・沿海州の一部(今泉, 1960)には T. s. lineatus が分布する．岸田（1924）は本種を亜種に細分せず，総 て T. asiaticus (GMELIN) とした. 一方, 黒田 (1938) は地方型を認め, 北海道・サハリン産をT. asiaticus lineatus (Siebold), 南千島産を T. a. okadae KuRODA, 朝鮮 座を T. a. uthensis (PALLAS) とした. エゾモモンカ Pteromys volans orii ; $P$. volans はニーラシア大陸 の北部・モンゴル・中国北東部・朝鮮・サハリン・北海 道に分布する. 千島・本州以南には産しない. 北海道産 はP. v. orii である. 岸田 (1924) ・黒田 (1938) らは 北海道産を $P$. v. orii (KURODA), サハリン産を $P . v$. athene (Thомаs) とし, さらに黒田（1938）は朝鮮産 をP.v.aluco (Thomas) とした。一方, 今泉 (1949) は北海道産をP.v. orii (KURODA) とし, 本州・九州産 を別重種 P.v. amygdali (THOMAs) とした. しかし，そ の後北海道産と本州・九州産とでは, 陰茎骨の形態が全 く異っていることがわかり，各々別種として記載される ようになった.ミカドネズミClethrionomys rutilus mikado; C. rutilus は北米・ユーラシア大陸の北部・ モンゴル・中国北東部・サハリン・北海道に分布する. 岸田（1924）はシベリア・サハリン産を Evotomys amurensis (SCHRENCK) とし, 北海道産をその地方型 $E$. a. mikado (THOMAS) とした. 黒田（1938）は属を変更し 前者を Clethrionomys amurensis (SCHRENCK), 後者を C. $a$. mikado (Thomas) とした. Ellerman \& MORRISONSCOTT （1951）は沿海州・サハリン産と北海道産とは 区別が困難であるとしこれらを総て Clethrionomys rutilus amurensis (SCHRENCK) とした. 今泉(1949)は北海道産 が基亜種に比べ，尾長く聴胞が小であるとして C. r r mikado (THOMAS) としたが，その後北海道産と沿海州・ サハリン産とは区別困難であることを指摘している(19 60). エゾヤチネズミ Clethrionomys rufocanus be dfordiae : C. rufocanus はューラシア大陸の冷温帯以北 ・サハリン・北海道とその属島・南千島に分布する. 北 海道・南千島産は基覀種よりやや大形の C.r. bedfordiae である．黒田（1938）は日本産ヤチネズミを記載するに 
当たり，北海道・南千島・サハリン産を C. r. bedfordiae, 北千島産を C. $r$. rufocanus (SUNDEVALL), 本州北部産 を C.r. andersoni (THOMAS), 本州中部以南産を $C . r$. smithii (Thomas) とした. Ellerman \& MorrisonScotT (1951) は沿海州・サハリン・北海道から九州ま での日本産を総て C. r. smithii (ThomAs) とした. 今 泉 (1949) は北海道・南千島産を C. r. bedfordiae, 本州 中部以北産を C.r. andersoni (ThOMAS) としたが，そ の後白歯の形態が北海道産は有根で本州以南産は無根で あることが解り，本州産を別属とした. リシリヤチネズ ミClethrionomys rex : 本種は IMAIzUMI (1971) により報告された種で，大雪・日高・利尻・礼文に分布 する. ABE (1973) は本種がサハリンおよび大陸にも生 息している可能性を指摘している. ABE et al. (1971) ・IMAIZUMI（1971）らは頭骨・歯・尾・体色などから C. rex が C.r. bedfordiae (THOMAS) と C. sikotanensis （TOKUDA）の祖先型に近縁であることを指摘している. ムクゲネズミClethrionomys sikotanensis : 本種は TOKUDA (1935) が色丹島産に対し Neoaschizomys sikokanensis と命名し, その後, 属を Clethrionomys に変更し たものである. 本種は色丹島・大黒島・利尻・礼文に産 するとされているが，ABE（1973）によると，色丹島産 と大黒島産とでは形質に差異があるとのことであり，同 一種であるか否か検討を要する．ABE (1973) による と, C. sikotanensis は C.r. bedfordiae よりもC.rexに 近縁であり，大黒島産はこの島が北海道から分離後 C. rex 類似祖先から分出したと推論している. エリ゙アカ ネズミApodemus speciosus ainu：A. speciosus は 朝鮮・日本・国後島に分布する. 小林 (1972) によると 中国・沿海州にも産する可能性がある. ToKUDA (1941) は北海道産が本州産に比べ切歯孔が細長いこと, 吻部が 幾分長いことを基に，独立種 A. ainu とした. КовAYASHI \& HAYATA (1971) は北海道産を A.speciosus の 特殊変種とし, karyotype analysisを基に, 北海道産と本州 産とは区別困難なことを指摘した．更に，小林 (1972) はA. speciosus は A. favicollis の特殊化が進んだもの とし，A. speciosus の種内に 3 段階を認め, 各段階に亜 種的変異が存在するとし, 最も特殊化の低位の種が沿海 州から朝鮮にかけて分布し, 更に特殊化の進んだ種 $A$. s. speciosus が本州・四国・九州に産し, 最も特殊化の進 んだ種 A. s. ainu が北海道に産するとしている. カラ フトアカネズミApodemus giliacus : 本種は中国北 東部・沿海州・東シベリア・サハリン・北海道に分布す る. 本種は従来, Micromys speciosus giliacus THOMAS,
Apodemus ainu peninsulae TOKUDA, A. sylyaticus giliacus ELLERMAN et al. などと記載され，産地はサハリンの みとされていたが, KOBAYASHI \& HAYATA (1971), 小林 (1972) らの形態学的および染色体学的研究により 独立種とされ，更に本種は Apodemus の祖先型に近縁の 種とされた.エソヒメネズミApodemus argenteus hokkaidi；A. argenleus は日本特産種で全国の森林地带 に広く分布する. THOMAS (1905) により argenteus は A. speciosus の幼獣に対し与えられた名称であると誤証 され，本種の種名が geisha と変更された，以来，黑田 （1938）・青木 (1915) · ToKUDA (1941) · 今泉 (1949) らにより geisha の種名が採用されていたが，今泉（19 60)は Temminck \& SCHLEgel (1845) の原記載支検 討し, 改めて argenteus を復活させた. 黑田 (1938), 今 泉（1960）らは本種について地方型を琴め, 北海道産を A. a. hokkaidi, 本州・四国・ 九州産を A. a. argenteus など垔種に細分したが，小林 (1972)は本種が Apodemus の中で最も地理的変異が小さいとし, 雨種を珰めていな い.

以上の他に MURIDAE としてエゾハツカネズミMus musculus esonis ; ニホンクマネズミRattus rattus tanezumi； ニホンドブネズミ Rattus norvegicus caraco を産する.

食肉目は次の 5 科13属 8 種・ 9 西種を産する. エゾヒ グマUrsus arctos yesoensis : U. arctos はユーラシ ア大陸の北部・サハリン・北海道・千島・北米に分布す る. 日本では北海道の平地から山岳地带にかけ広く産し ，その数は 3,000 頭と見られている(犬飼)，北海道・ 南千島産は $U$. a. yesoensis, サハリン・北千島産は $U$. a. beringianus MIDDENDORFF である.これら地方型につ いて MukasA（1937）は, サハリン産 4 個体と北海道 産97個体の頭骨を比較し, 北海道に島岨的地方型の存在 を認めている. エソオオカミCanis lupus hattai ; C. lupus はニーラシア大陸とその属島・北米に広く分布 していたが, 被害防除上, 絶滅させられた地域が多い。 本州・四国・九州には C. $l$. hodophilax TEMMINCK \& SCHLEGEL が,サハリン・北海道・南千島には C.l. hattai KISHIDA が広く分布していたが，北海道から九州にか けては絶滅したようである。 C.l. hattai の地方型は KISHIDA（1931）により記載されたが，その根拠は同一 大陸の朝鮮・沿海州・カムチャッカなどに执いて, 既に 地方型が認められている故, それらの地域から隔離され ている北海道産は当然地方型として区別されるべきとの 考えによる.エリタタキ Nyctereutes procyonoides 
albus : N. procyonoides は中国・朝鮮・沿海州・日本に 分布する．サハリン・北千島には産しない，岸田(1924) は北海道産が本州以南産に比べ頭胴長と後肢が特に長大 であるとして各々を別種とし，北海道産を N.p. albus BEARD 本州・四国・九州産を N.p. viverrinus TEMMINCK とした，黒田（1938）は日本産它 N. procyonoides の西 種とし, 北海道産を $N$. p. albus BEARD, 本州以南産を N. p. viverrinus TEMMINCK et al. とした. 今泉 (1949) は黒田の記載老採用しつつも，石井・三島 (1940)によ る日本各地産のタヌキ90頭の調査から，体長・毛皮には 普遍的地方差が認められないとの成績を基に，地方型の 存在に疑問を示している.南千島には $N . p$. albus を産 する.キタキツネVulpes vulpes schrencki : V. vulpes は北アフリカ・ユーラシア大陸と北米の温帯以北に広く 分布する，日本にも多産する．黑田 (1938) - 今泉(1949, 1960）らは体の大きさと毛皮の上に地方差を認め，サハ リン・北海道・南千島産を V. vulpes schrencki KISHIDA, 本州・四国・九州産を V.v. japonica GRAY とした。岸 田（1924）は千島中部以北産を $V . \quad \%$ splendidissima KISHIDA とした. エソクロテン Martes zibellina brachyura : $M$. zibellina は北ヨーロッパ・シベリア・ 中国の中部以北・朝鮮 : サハリン・千島・北海道に分布 する. 岸田 (1924) は極東産を総て M. zibellina と記載 したが，その後朝鮮産に地力型を認め $M$. . z. hamgyenensis KISHIDA とした (1927). 黑田 (1938) は体の大きさと 毛皮の上に地方差を諗め, サハリン産をM.z. sahalinensis OGNEV, 北海道・南千島産支 $M . z$. brachyura，北千島産 老 M. z. kamtshadalica (BIRULA), 朝鮮中部以北産を $M$. z. hamgyenensis と記載した. ニホンイタチ Mustela sibirica itatsi : M. sibirica はアジア大陸に広く分布し, 日本でも北海道から九州およびその属島に至るまで広く 分布している. 北海道（犬飼, 1934 a) には偶然に移入 されたもので（サハリンには北海道から移入した。 犬飼，1949），岸田（1924）は日本産を総て M. i. ilatsi TEMMINCK et al. と記載し, 黒田 (1938) は北海道・本 州・四国・ 九州産を $M$. i. itatsi, 屋久島・種子島を $M$. i. sho (KURODA), 朝鮮北部 - 中国北東部産を $M$. sibirica manchurica BRASS, 朝鮮中部以南産を $M$. s. coreanus DOMANIEWSKI と記載した. その後日本産は $M$. sibirica の地方型と同定され今日に至っている. 地方型の差異に ついては M. s. sho が $M$. s. itatsiより小形である他は明 確でない. ニホンイイズナ Mustera nivalis namiyei : M. nivalis はユーラシア大陸の北部・中国・朝鮮北部 ・サハリン・南千島・北海道・本州北部に分布する. 本
種は最初, 波江・青木（岸田，1924）らによりヨーロッ 孫の M. nivalis の地方型として記載されていたが，岸 田(1924) ・黑田(1938)・今泉 (1949) らにより, 北米産 の Mustera rixosa BANGS と同定され, 日本・サハリン 産はその地方型 $M . r$. namiyei KURODA とされていた. しかし, その後再検討され再び $M$. nivalis の地方型 $M$. n. namiyei KURODA とされ今日に至っている（今泉, 19 60 ; 他). エソンオコジョ Mustera erminea orientalis : M. erminea は北米・ヨーロッパ・中国北東部・東シ ベリア・サハリン・北海道・南千島・本州中部以北に分 布する. 北海道と本州北部では平地に本州中部では山岳 地带に分布する．岸田（1924）・黒田（1938）は本州産 を $M . e . n i p p o n$ BAIRD, サハリソ・北海道・南千島産を M. e. kanei (BAIRD) と記載した. 今泉 (1949) は沿海 州・サハリン・北海道・南千島産を, ヨーロッパ北部産 をの基亚種 M.e. erminae より体の大きさがやや小さく 尾も短小であるとし，M.e. kanei (BAIRD) と記載した. 更に本州産は M. e. kanei よりも更に小さいとし M.e. nippon とした。 その後今泉（1960）は ELLERMAN \& MORRISON-SCOTT (1951) の記載に従い M. e. kanei の 业種名を M. e. orientalis OGNEv と変更した. チシマア ザラシ Phoca kurilensis ： 本種は犬飼 (1942) が Phoca vitulina の変種として報告し, 後に БЕлкин (1964) が独立種として記載したものである.本種は P. vitulinaに 酷似しているが，内藤（1973）によると舌骨の形状に顕 著な差異がある．即ち本種は多くのアザラシ類にある鼓 室舌骨を欠き，さらに茎突舌骨の大ささが P. vitulinaの 10 分の 1 程度にすぎない，このことで両種は完全に区別 しえる.なお，日本産アザラシ類の和名の多くは外形態 上の特徴により命名されているが，犬飼は本種の分布が 主として千島であることからチシマアザラシの和名を与 えた.しかし近年, 外形態上の特徴からゼニガタアザラ シなる呼称も使われているが，犬飼は本種をチシマアザ ラシと呼ぶことを主張している.

以上の他に MUSTELIDAE としてニホンカワウソ Lutra lutra whiteleyi, ラッコ Enhydra lutris ; OTARIIDAE としてトドEumetopias jubata, オ ッセイ Callorhinus ursinus ; PHOGIDAE とし てアゴヒゲアザラシ Erignathus barbatus, クラカケ アザラシ Histriophoca fasciata, フイリアザラシ Phoca hispida, ゴマフアザラシ Phoca vitulina が 記載されている。この中, Lutra lutra whiteleyi と Enhydra lutris は近年北海道では見られなくなったが, その残存に ついては疑問とされている. 
偶蹄目は次の 1 科 1 属 1 业種を産する. エゾシカ $\boldsymbol{C e}$ rvus nippon yesoensis : C. nippon は中国・朝鮮・沿 海州南部・日本とその属島に分布する．岸田 (1924) は 松本 (1918) の古生物学的研究加ら北海道と本州北部に は C. nippon の他に Crevus が生息しているとの報告を基 に，C. matsumotoi KISHIDA なる種を記載した。黑田 （1938）は本種を認めず，北海道・本州・四国・九州・ 対島・屋久島・朝鮮産を総て $C . n$. nippon TEMMINCK とした. 犬飼は生態学上から黒田の見解を支持している。 その後, 今泉 (1949) は主として体の大きさにより地方 型を認め, 北海道産を C. n. yesoensis, 本州・対馬産を C. n. centralis KISHIDA, 四国 · 九州 ·屋久島 ·種子島産 をC.n. nippon TEMMINCK とした. その後，更に今泉 （1960）は屋久島産を別亜種 C. n. yakushimae KURODA et al. とした.

\section{III 考察および結論}

\section{1. 現存北海道産哺乳類の由来について}

先史時代における先住民族の貝塚などからの獣骨の産 出は別として, 現存日本産哺乳類の化石が北海道から産 出した記録はない.しかし，本州などからは現存種の化 石が少数ながら第四紀洪積世以降の地層から産出してい る（直良，1944; 阿部余四男，1955）。この事実から， 現存種またはそれに極めて近縁の種が，日本列島に出現 したのは第四紀以降と考えられる。しかし，日本産哺乳 類の中, 大部分のものは大陸との共通種か, 極めて近縁 の種であり, 日本特産種と言われているものも, その類 縁を辿ると, その祖先型は総て大陸に求められる. 従っ て, 現存日本産哺乳類の殆んど総てのものが何らかの形 で，かつて大陸と交流があったと考えねばならない，第 四紀以降の大陸と日本列島間に，日本の現存哺乳類の分 布域を合理的に説明し得るような経路を求めるとすれば, 北方に 1 ないし 2 経路, 南方に 2 経路の存在を認めねば ならない.すなわち, 北方の 2 経路とは沿海州からサハ リンを経て北海道に至るものと，カムチャッカから千島 列島を経て北海道に至るものとである. 後者の経路は約 30 万年前の第 2 間水期にウルップ水道が成立し陸路とし ての交通路が断絶したことから，北方動物の日本列島へ の進入経路としての価值は前者より低いものと考えられ， ウルップ水道以南の島々には逆に北海道からの進入種が 多いものと思われる.このことはこれら島に産する殆ん どの種が, ウルップ水道以北の島々と異なり, 北海道と の共通種であることからも推察しえる. 一方, 前者の経 路は宗谷海峡が成立した約 1.2 万年前の後水期の初期ま
で存在していたとみられ，この経路を経て大陸の北部森 林地帯の多数の動物が日本列島に進入したと考えられる. 現存北海道産哺乳類中Sorex minutissimus, Sorex gracillimus, Sorex caecutiens, Sorex unguiculatus, Ochotona hyperborea, Lepus timidus, Sciurus vulgaris, Timias sibiricus, Pteromys volans, Clethrionomys rutilus, Clethrionomys rufocanus, Clethrionomy srex, Apodemus giliacus, Ursus arctos, Martes zibellina, Mustela nivalis Mustela erminea などがこの 経路の南下組とみられ, 多分北海道産の Canis lupus, Vulpes vulpes もそうであろう.さらに, これらの中，い くつかの種またはその祖先型は本州以南へも南進し たとみられ，北海道産の Sorex minutissimus, Lepus timidus, Sciurus vulgaris, Clethrionomys rex は本州では Sorex hosonoi, Lepus brachyurus, Sciurus lis, Aschizomys \& Eothenomys に特殊化した可能性も考えられる. Ursus arctos の化石分栃木県加産出しているから, 多分北海 道から南進した時代があったのかもしれないここの 他，本州または四国まで分布を広げたものに Sorex caecutiens, Mustela nivalis, Mustela Erminea がある. 南 方の 2 経路とは, 大陸から朝鮮半島を経て本州・九州に 至るものと，大陸加ら朝鮮半島を経ず，東シナ海寄りの 経路を経て九州・本州に至るものとである. 前者の経路 を経て北海道まで分布を広げて来たと考えられるものに Crocidura dsinezumi, Apodemus speciosus, Apodemus argenteusなどの祖先型, Cervus nippon, Nyctereutes procyonoides などがある，後者の経路を経て列島に分布を去げて来た 種にMacaca fuscata, Paguma larvataなどがあるが，いつ れも北海道にまで至っていない。この他，広域分布をな す北海道産哺乳類にMus musculus, Rattus rattus, Rattus norvegicus, Canis lupus, Vulpes vulpes, Lutra lutra がある が, M. musculus, R. rattus, R. norvegicus は南方経路か ら，C. lupus, V. vulpes, L. lutra は北方経路からそれぞ れ北海道に進入，分布を広げたものと考えられる。

北海道が完全な孤島になったのは，宗谷海快が形成さ れた後氷期の初期であるから，その後に特殊変種化した と考えられる Clethrionomys sikotanensis (ABE, 1973), 明治以降の移入種である Mustela sibirica（犬飼,1934 a ) Rattus rattus を除き，この時期までに現存北海道産哺乳 類の殆んど総ての種またはその祖先型が北海道に定着し たと考えられる. 現今では, 個々の種が北海道に進入・ 定着した正確な年代を論づるだけの資料がなく，それは 不可能であるが，いづれにしても第四紀以降であること は間違いないものと考えられる。

2. 北海道の哺乳相とその動物区について 
北海道の哺乳相の特徴を指摘するならば，アジア大陸 に広く分布している広域分布種，大陸の寒帯林以北に主 として分布している北部森林地区系種, 大陸の温帯林地 区に近縁種を有する温帯林地区系種との混棲地带である こと, そして陸棲哺乳類の他に海棲哺乳類を多産するこ とが上价られる。北海道産の広域分布種にはVespertilio superans, Plecotus auritus, Murina aurata, Mus musculus, Rattus rattus, Rattus norvegicus, Canis lupus, Vulpes vulpes, Lutra lutra などが, 北部森林地区系種には Sorex minutissimus, Sorex gracillimus, Sorex caecutiens, Sorex unguiculatus, Ochotona hyperborea, Lepus timidus, Sciurus vulgaris, Tamias sibiricus, Pteromys volans, Clethrionomys rutillus, Clethrionomys rufocanus, Clethrionomys rex, Clethrionomys sikotanensis, Apodemus giliacus, Ursus arctos, Martes zibellina, Mustela nivalis, Mustela erminea, Enhydra lutris, Eumetopias jubata, Callorhinus ursinus, Erignathus barbatus, Historiophoca fasciata, Phoca hispida, Phoca vitulina, Phoca kurilensis などが, 温带林地区系種には Crocidura dsinezumi, Apodemus speciosus, Apodemus argenteus, Rhinolophus cornutus, Rhinolophus ferrum-equinum, Nyctalus lasiopterus, Barbastella leucomelas, Nyctereutes procyonoides, Cervus nipponなどがある

北海道の近接地域について, 哺乳相を比較してみると, 沿海州北部・東シベリア・カムチャッカ・サハリン・北 千島は総て広域分布種と北部森林地区系種のみから成 り, 大半が北部系種である. 中国北東部 - 朝鮮北部 - 北 海道・南千島は 3 系種の混棲地带で, 大半が北方系種と 広域種から成り，それに少数の温带系種が混じている. 本州北部は温带系種と広域系種が大半を占め, それに少 数の北方系種を混じている.九州は広域系種と温帯系種 のみから成り，その大半が温带系種である.このように 北海道から北離または南離するにつれ，広域分布種は不 変であるが, 北部森林地区系種と温帯林地区系種の割合 が反比例する関係にある。しかも，これら地域内の哺乳 相は，いづれの地域でもその隣接地域とは，全種が明確 に画されるものではなく，隣接地域間に海峡を有してい ても，相の上では常に連続的移行型を形成していると言 える.

北海道の動物区について今泉 (1970) は, 北海道の哺 乳相がアジア大陸の北部森林地区の相と酷似していると し，北海道を北部森林地区に包含させた。そしてサハリ ン以北には温帯林地区系種を産しないが，北海道にそれ が少数だが産するとし，北海道小区としてサハリン以北 および本州以南と区別した。ささらに今泉は宗谷海峡が温 帯林地区系種の北限になっている点を指摘し，八田ライ
ソの哺乳相上の意義を認めている，この見解は現状では 極めて妥当と考えられるが，沿海州・サハリン地区にも 温帯系種の Apodemus speciosus を産する可能性があり, 研究の進行とともに北海道小区の意義も変わる可能性が ある．南千島は北千島と異なり，北海道と同様 3 系種の 混棲地で, しかもその全種が北海道との共通種であるか ら北海道小区に包含されるべきと考苀る.

\section{3. 北海道産哺乳類の分類学上の問題点について}

現存北海道産哺乳類は 6 目14科34属 19 種・34两種の53 種類が記載されているが，これまでの分類の主流が，成 体の比較形態学的研究に基づく人為分類的なもので，広 範な系統発生学的研究を基盤とした分類でなかったため, 現在なお属・種などの記載変更がなされており, 今後研 究の進行とともに, さらに変更されるものがあると考え られる。

ABE (1973) は北海道産 Clethrionomys について系統 発生学的研究老行ない, Clethrionomys rex が Clethrionomys の祖先型に極めて近縁な種で, Clethrionomys sikotanensis, Clethrionomys rufocanus ともこの祖先型から各々 分化した可能性を指摘した. 北海道の属島の C. siko$t_{\text {anensis }}$ は今泉 (1960) により色丹島産の C. sikotanensis と同一種と同定されたが，ABE (1973) は大黒島と色 丹島産とでは形質に差異があることを指摘している。ま た Clethrionomys と本州に産する Aschizomys，Eothenomys との類縁関係も明らかではなく，これらは今後系統発生 学的研究により類縁関係を明らか心する必要がある. Sorex minutissimus は北海道を南限としているが, 本州中 部にはSorex hosonoi 在産する. 両種は歯・頭骨の形態 が酷似しているが類縁関係は不明である，さらに日本産 リスとノウサギは主として成体間の比較形態学的研究を 基に，北海道と本州以南とで各々別種に記載されている が, これらは両種間の繁殖力の強弱, 発生・成長のパター ンの比較研究を行ない類縁関係を明確にする必要がある。

既存の雨種の区分については，その殆んどが少数の標 本に基づてなされており，はたして分類学上亜種にま で細分することが合理的であるか否か明確でない場合が 多い, 従って, 亜種の区分については今後さらに, 多数 の標本について令変異・雌雄間変異・個体間変異などを 十分比較検討し, 普遍的な不連続的地理変異が存在する か否かについて再検討する必要がある.

\section{4. 北海道産哺乳類の分布上の問題点について}

北海道で主に平地に産する北方系種の Mustela nivalis, Mustela erminea は本州まで，Sorex caecutiens は四国ま で分布を広げているが，北海道から南離するにつれ寒冷 
な山岳地带にその生息地が移行している. 温带系種の Nyctereutes procyonoides, Cervus nippon は大陸では沿海州 南部まで, 日本では全国に広く分布しているが，サハリ ソ・沿海州北部には産しない: 北海道を北部・東部・南 部と大別すると, 北部と東部で, 南部と本州北部で各々 分布域上連続する種が多い.これらは，動物の分布が地 理的条件の他に気候を主体とした自然環境に強く制約さ れている例と言える.これに対し, 北海道産の Mustela sibirica は移入種で現在広く分布しており (犬飼, 1934), 多分 Rattus rattus 女移入種と考えられるが，これも現 在分布域を拡大しつつある.これらは順化能力を有して いる種が，一度地理的隔離から解放されると，自然を最 大限に利用する方向へと分布域を拡大して行くものであ ることの例と言える.

Crocidura dsinezumi は札幌・芦別で, Sorex minutissimus は東部と北部で極めて局限された地域でのみ生息が確認 されているに過きず，Ochotona hyperborea の知床地域で の生息はまだ未確認である.これらの種がはたして現況 のような分布域形態であるか否かは生態上・動物地理学 上興味ある問題である.

千島地域の哺乳類についての記載は SNOW (1885, 19 10), 犬飼 (1934), 黑田 (1938), 岡田 (1938) などが あるが，今後詳細な現地調査を行なえば，さらに追加さ れる種も相当あるものと考えられる.

北海道て Canis lupus は家畜の被害防除上(犬飼1933), Lutra lutra は毛皮獣として, 多量に捕殺されたため今日 では絶滅したと思われる，近年，Vulpes vulpes のpopulation が大きくなっているが,これは天敵関係にある Canis lupus が皆無であることも， その増長を許容していると 考えられる。

\section{引用 文 献}

阿部余四男 (1944) 沖ノ島附近のオオカミカウモリ属. 動 雑, 56 (1-3), 59.

阿部余四男 (1955) 日本哺乳動物相の由来. 生物地理会報, 16-19, 384-388.

阿部 永 (1961) 北海道にて採取された稀種オヒキコウモ リ及びトウキョウトガリネズミについて. 哺乳動物雑, 2, 3-7.

ABE, E. (1967) Classification and biology of Japanese Insectivora. J. Fac. Agr. Hokkaido Univ., 55, $191-$ 265.

ABE, E. et al. (1971) Results of the small mammal survey on the Daisetsu area. Ann. Rep. JIBP/CT-S
$1970,13$.

ABE, E. (1973) Growth and development in two forms of Glethrionomys. J. Fac. Agr. Hokkaido Univ. 57, $229-274$.

青木文一郎 (1915) 日本産単科. 東京動物学会特別出版, 88 pp.

Белкин, А. Н. (1964) Новый вип Тюленяс Курильских Островов-Рноса insularis sp. n. Доклады Академии Наук СССР., 158, $1217-1220$.

Blakiston, T. \& Pryer, H. (1880) Catalogue of the birds of Japan. Trans. Asia Soc. Jap., 10, 85.

Blakiston, T.(1883) Zoological indications of ancient connection of the Japan islands with the continent. Trans. Asia Soc. Jap. 2, 126--140.

Ellerman, J. R. \& MORRISON-ScotT, T.C.S. (195 1). Checklist of Palaeoarctic and Indian mammals. London. HatTA' S. (1913) Zur Tiergeographie von Hokkaido Zool. Anz., 43, 27-36.

服部畦作 (1966) 北海道産コウモリについて. 北海道衛生. 研報， 16，69-77.

服部畦作 (1971) 北海道産翼手目に関する研究. 北海道衛 生研報, 21, 68-100.

今泉吉典 (1949) 日本哺乳動物図説, 348 pp., 洋洋書房.

IMAIZUMI, Y. (1954) Taxonomic studies on Japanese Myotis with descriptions of three new forms (Mammalia chiroptera). Bull. Nat. Mus. (Tokyo), N.S. 1, (1), 40-58.

IMAIZUMI, Y. (1955) Systematic notes on the Korean and Japanese bats of Pipistrellus savii group. Bull. Nat. Mus. (Tokyo), N. S., 2, (2) 54-63.

今泉吉典 $(1960)$ 原色日本哺乳類図鑑. 196pp. 保育社, 大阪.

今泉吉典 (1963) 対島産モモジロコウモリについて, 哺乳

動物雑. 2, (2), 53-54.

今泉吉典・吉行端子 (1965) 日本産オヒキコウモりの分類 学的考察, 哺乳動物雑, 2, (4), 105-108.

今泉吉典 (1970) 日本哺乳動物図説 (上). $350 \mathrm{pp}$, 新思潮 社, 東京.

IMAizUmI, Y. (1971) A new vole of the Clethrionomys rufecanus group from Rishi Island, Japan. J. Mamm., Soc. Jap. 5, (3), 99-103.

犬飼哲夫 (1933) 北海道産狼とその滅亡経路, 植動, 1, (8), 1091-1098.

犬飼哲夫 $(1934 \mathrm{a})$ 即の北海道内僈入経路とその利用，植 
動, 2, (8), 1309-1317.

犬飼哲夫 $(1934 \mathrm{~b})$ 千島の動物概観. 千島概況, 北海道庁: pp. $87-99$.

犬飼哲夫 (1942) 吾が北洋の海豹（アザラシ） [1]，植動, 10, (10), 927-932.

犬飼哲夫 (1949) 野単駆除のため北海道近島へイタ千放

飼とその成績, Trans. Sapporo Nat. Hist. Soc., 18, 56. 石井時彦 ・三島康七 (1940) 狸の体格に関する統計的研究.

毛皮獣養殖所年報, 7-22.

岸田久吉 (1923) ジャカウネズミに就て, 動雑, 36, 156159.

岸田久吉 (1924) 哺乳動物図解。 $381 \mathrm{pp}$. 農商務省農務

㕍，東京。

岸田久吉 (1927) 鳥獣調查報吉 4

KISHIDA, H. (1930) Diagnosis of a new piping hare from Yeso. Lansania, 2, 45-47.

Kishida, H.(1931) Notes on the Yesso wolf. Lansania, $3, \quad 72-75$.

岸田久吉・㷊為三(1931) 朝鮮産陸棲哺乳動物り分布に 就いて, 動雑, 43, 372-391.

Kobayashi, T. \& Hayata, I. (1971) Revision of the Genus Apodmus in Hokkaido, Annat. Zoo. Jap., 44, 236--240.

小林恒明 (1972) 本邦産 Apdemus 属の系統分類学的研究, 学位論文. $309 \mathrm{pp}$.

KURODA, N. (1928) The mammal fauna of Sahalin. J. Mamm., 9, 222. - 229.

黑田長禮 (1938) 日本産哺乳類目録. 122pp., ヘシルド社 (丸善), 東京.

黑田長禮 (1940) 原色日本哺乳類図説. 311 pp.，：省堂， 東京.

黒田長禮 (1953) 日本獣類困説, $177 \mathrm{pp}$. 創元社, 東京.
松本彦七郎 (1918) 津軽海峡の意義. 動雑, 30, 466-468. MukASA, K. (1937) The growth of the crania of Yeso brown bear. Trans. Sapporo Nat. Hist Soc. 15, 96.

野沢俊次郎 (1894) 千島の動物, 動雑. 6, 282-286

OGnev, S. I. (1927) A synopsis of the Russian bats. J. Mamm., 8, $140-157$.

OKADA, Y. (1938) A calalogue of vertebrates of Japan. 410 pp., Maruzen, Toky

值良信夫 (1944) 日本哺乳動物文, 265 pp., 餋德社.

Стротанов, С. У. (1957) Звери Сибири, Насекоядные, Москва.

Snow, H. J. (1885) Notes on the Kuril Islands. 308 pp., London.

SNow, H. J. (1910) In forbidden seas. London.

Temminck, C. J. \& SChlegel (1842-1845) Siebold's Fauna Japonica.

Thomas, O. (1905) The Duke of Bedford's zoological expedition in Eastern Asia. Proc. Zool. Soc. London, $331-363$

Thomas, O. (1907) List of small mammals from the islands of Sahaline and Hokkaido. Proc. Zoo. Soc. London. $404-414$

Tokuda, M. (1935) Neoaschizomys; a new genus of Microtinae from Sikotan, a South Kurile island. Mem, Coll. Sci., Kyoto Imp. Univ., B. 10, 241-259.

TokudA, M. (1941) A revised monogragh of the Japanese and Manchou-Korea Muridae. Trans. Biographical Soc. Jap. 4, 1-156.

Юдин, Б. С. (1965) Новый для фауны ссср вид эвмлеройки. Новые И Мапоизвестные виды Срауны Сибири А. И. Черепанов, 44-47. 